\title{
PENGARUH PANDANGAN INVESTASI INVESTOR INSTITUSIONAL TERHADAP KREDIT RATING PERUSAHAAN
}

\author{
Fenny Marietza \\ Program Studi Akuntansi, Fakultas Ekonomi dan Bisnis, Universitas Bengkulu \\ Mari3tza@gmail.com \\ Indah Oktari Wijayanti \\ Program Studi Akuntansi, Fakultas Ekonomi dan Bisnis, Universitas Bengkulu \\ Indahoktari24@gmail.com
}

\begin{abstract}
Abstrak: Pengaruh Pandangan Investasi Investor Institusional Terhadap Kredit Rating Perusahaan. Penelitian ini bertujuan untuk mengetahui seberapa besar peran investor institusi terhadap kenaikan atau penurunan rating kredit di Indonesia. Objek penelitian ini adalah perusahaan yang terdaftar di Bursa Efek Indonesia dari tahun 2017-2018. Pemilihan sampel dalam penelitian ini menggunakan metode purposive sampling. Berdasarkan hasil penelitian dengan menggunakan bantuan software SPSS dapat diambil kesimpulan sebagai berikut: pandangan investor terhadap kredit rating perusahaan secara signifikan terbukti berpengaruh. Pandangan investasi investor institusional diduga memiliki peran tata kelola untuk menjaga dan mengawasi efek dari asimetri informasi. Investor institusi yang cenderung memiliki pandangan investasi jangka panjang lebih memainkan peran pengawasan dibandingkan dengan investor institusional yang memiliki pandangan investasi jangka pendek sehingga adanya rating kredit mempengaruhi kebijakan penagawasan.
\end{abstract}

Kata Kunci: Pandangan Investasi, Investor Institusional, Kredit Rating Perusahaan

Abstract: The Effect of Institutional Investor Investment Views on Company Kredit Rating. This research aims to find out how much the role of institutional investors in the increase or decrease in kredit ratings in Kredit. The object of this research is companies listed on the Kredit Stock Exchange from 2017-2018. The sample selection in this study uses a purposive sampling method. Based on the results of research using SPSS software the following conclusions can be drawn: the investor's view of the company's kredit rating is significantly proven to be influential. The view of institutional investor investment is thought to have a governance 293olet o safeguard and oversee the effects of information asymmetry. Institutional investors who tend to have a long-term investment view play a supervisory role more than institutional investors who have a short-term investment view so that the kredit rating influences supervision policies.

Keywords: Institutional Investor, Investment Views, Company Credit Rating

\section{PENDAHULUAN}

Selama beberapa periode, investor intitusional telah berkembang dan bertumbuh dalam dunia investasi, seperti halnya di Amerika, investor institusional memiliki pengaruh yang signifikan terhadap penyediaan modal di pasar modal. Di Indonesia, investor institusi berperan sebagai penjaga stabilitas pasar modal dikarenakan semakin meningkatnya portfolio investor institusi lokal dalam reksadana dan saham maupun obligasi.

Kepemilikan saham maupun reksadana dalam jumlah yang besar, memungkinkan bagi investor institusi untuk memiliki peran aktif dalam memonitor, mengumpulkan 
informasi dan menjadi penengah dalam investasi perusahaan dan pengambil keputusan keuangan perusahaan. Investor institusi juga mendapatkan informasi terkait dengan kepemilikan saham dan reksadananya secara privat (khusus) yang dapat meningkatkan informasi perusahaan dan mengurangi asimetri informasi yang ada antara pihak investor internal maupun inverstor eksternal perusahaan (Shleifer \& Vishny, 1997). Beberapa penelitian yang telah dilakukan menduga bahwa dua pandangan yang saling mempengaruhi yaitu pandangan bahwa investor institusi memiliki peran sebagai tata kelola yang akan mengawasi perusahaan dan mengawasi asimetri informasi yang terjadi dalam perusahaan.

Pandangan investasi jangka panjag akan berkaitan dengan hubungan investasi yaitu kepemilikan, institusi akan mengurangi masalah "pengendara bebas" dalam perusahaan, adanya investor institusi akan memunculkan pemantauan yang lebih efektif yang menyebabkan manajer menampilkan prilaku yang lebih baik lagi dari sebelumnya yang terlalu mementingkan kepentingan manajer itu sendiri, sehingga akan menimbulkan hasil yang positif terhadap seluruh pemilik saham perusahaan.

Selain peran tata kelola, investor institusi juga memainkan peran informasi, beberapa orang menduga bahwa investor institusi jangka Panjang memiliki keunggulan informasi yang berasal dari kemampuan mereka untuk berinvestasi lebih banyak di perusahaan investee, mereka juga terlibat dalam penelitian dan mengumpulkan dan memproses informasi perusahaan lebih efisien daripada investor institusi jangka pendek. Kredit rating perusahaan memiliki peran dalam menilai kualitas informasi dan pengungkapan perusahaan (Sengupta, 1998) dan juga memiliki peran dalam pendanaan perusahaan dan keputusan investasi yang akan diambil oleh investor (Blume, Lim, \& Mackinlay, 1998). Dengan adanya kepemilikian investor institusi didalam perusahaan yang memainkan peran sebagai pengawas dan peran informasi menjadi penentu akan tinggi atau rendahnya kredit rating sebuah perusahaan. Semakin banyak investor institusi didalam perusahaan maka akan menaikkan kredit rating sebuah perusahaan.

Di Amerika yang memiliki pasar modal yang efisien, banyak penelitian mengatakan bahwa kepemilikan institusi dalam sebuah perusahaan akan meningkatkan nilai kredit rating perusahaan tersebut, dimana investor institusi memiliki peran yang signifikan dalam pasar modal mereka. Di Indonesia peran investor itu sendiri masih belum dapat dibuktikan apakah dapat mempengaruhi naik atau turunkan kredit rating sebuah perusahaan. Berdasarkan latar belakang ini, 
maka penelitian ini bertujuan untuk mengetahui seberapa besar peran investor institusi terhadap kenaikan atau penurunan rating kredit di Indonesia.

\section{KAJIAN LITERATUR}

\section{Teori sinyal (Signalling Theory)}

Teori sinyal didasarkan pada adanya informasi yang diterima oleh masing -masing pihak yang berhubungan dengan perusahaan tidak sama. Jadi bisa dikatakan bahwa teori sinyal berkaitan dengan adanya asimetri informasi. Teori sinyal mengemukakan bagaimana seharusnya sebuah perusahaan memberikan sinyal kepada pengguna laporan keuangan. Sinyal berupa informasi mengenai apa yang telah dilakukan oleh manajemen untuk merealisasikan keinginan dari pemilik. Sinyal dapat berupa promosi atau informasi lain yang menyatakan bahwa perusahaan lebih baik dari perusahaan lainnya.

Brigham dan Houston (2001) menyatakan bahwa isyarat merupakan tindakan yang diambil oleh manajemen perusahaan yang merupakan petunjuk bagi investor tentang bagaimana manajemen memandang prospek perusahaan. Perusahaan dengan prospek menguntungkan akan mencoba menghindari penjualan saham dan mengusahakan setiap modal baru diperlukan dengan cara-cara lain. Sedangkan dengan prospek yang kurang menguntungkan akan cenderung untuk menjual saham.

\section{Struktur Kepemilikan}

Struktur kepemilikan terdiri dari kepemilikan saham oleh manajer dan direksi, kepemilikan saham oleh instutusi dan kepemilikan saham oleh pihak investor individual (Pujiati, 2015). Struktur kepemilkan dipercaya memiliki kemampuan untuk mempengaruhi jalannya perusahaan yang pada akhirnya dapat mempengaruhi kinerja perusahaan. Kepemilikan manajerial dan kepemilikan institusional adalah bagian dari struktur kepemilikan yang termasuk dalam corporate governance yang dapat mempengaruhi masalah keagenan.

\section{Kepemilikan Institusional}

Kepemilikan instutusional merupakan presentase saham yang dimiliki oleh pihak institusi dari keseluruhan saham yang beredar. Pihak instutional akan membantu perusahaan dalam pengawasan terhadap perusahaan sehingga manajemen tidak akan bertindak merugikan pemegang saham. Kepemilikan institusional yang lebih dari 5\% akan memberikan kemampuan yang lebih baik untuk memonitor manajemen. Berdasarkan (Connelly, Tihanyi, Certo, \& Hitt, 2010) investor intitusional dikelompokkan menjadi dua kelompok berdasarkan investment horizon dan fiduciary standards. Berdasarkan investment horizon investor institusional dibedakan menjadi 3 jenis yaitu dedicated investor, transient investor dan quasi indexer. Untuk 
jenis dedicated investor dicirikan dengan kepemilikan saham yang besar, investasi jangka panjang, melakukan portfolio dan menitik beratkan pada pertumbuhan perusahaan, dan beberapa dedicated investor melakukan pengawasan terhadap perusahaan secara ketat. Transient investor adalah pemilik sementara yang lebih focus pada laba sekarang, jika perusahaan banyak dimiliki oleh investor institusional jenis ini maka manajernya akan melakukan tindakan yang dapat menghasilkan laba jangka pendek, investor jenis ini juga akan menginvestasikan danannya dengan jumlah yang kecil. Jenis terakhir yaitu quasi indexer meripakan investasi yang dilakukan oleh pihak institusional dibeberapa perusahaan dan melakukan investasi jangka panjang, membeli dan menahan kepemilikan yang dimiliki sebagai strategi portfolio (Haryono, 2017).

\section{Kredit Rating}

Kredit ratingadalah penilaian yang diberikan oleh lembaga pemeringkata terhadap kualitas suatu obligasi yang diberikan oleh emiten. PT PEFINDO sebagai Lembaga pemeringkat kredit di Indonesia menyatakan bahwa pada umumnya pemeringkatan hutang merupakan indicator kemungkinan pembayaran bunga dan hutang tepat waktu sesuai dengan perjanjian yang telah disepakati.

\section{Manfaat Rating Bagi Investor}

Ada beberapa manfaat rating bagi para investor berdasarkan (Rahardjo, 2004) yaitu:

a. Informasi resiko investasi, dengan adanya peringkat kredit ini diharapakn informasi resiko dapat diketahui lebih jelas posisinya.

b. Rekomendasi investasi, investor dapat dengan mudah mengambil keputusan investasi berdasarkan hasil peringkat kinerja emiten obligasi tersebut.

c. Perbandingan, hasil rating akan menjadikan patokan dalam membandingkan obligasi yang satu dengan yang lainnya, serta membandingkan struktur yang lain seperti suku bunga dan metode penjaminnya.

\section{Hubungan Pandangan Invetasi Investor}

\section{Institusional dan Kredit Rating}

Pandangan investasi investor institusional diduga memiliki peran tata kelola untuk menjaga dan mengawasi efek dari asimetri informasi. Investor institusi yang cenderung memiliki pandangan investasi jangka panjang lebih memainkan peran pengawasan dibandingkan dengan investor institusional yang memiliki pandangan investasi jangka pendek. Semakin baiknya tata kelola di dalam perusahaan akan berdampak pada kualitas perusahaan dan dapat direfleksikan dalam peringkat kredit perusahaan. 
(Ashbaugh-Skaife, Collins, \& LaFond, 2006; Bhojraj \& Sengupta, 2003) mengatakan bahwa tata kelola perusahaan akan mampu menurunkan risiko perusahaan yang hasilnya akan membaiknya kredit rating dan obligasi rating perusahaan. Dalam penelitian ini lebih difokuskan pada kredit rating dibandingkan obligasi rating, dimana pandangan investasi jangka panjang dari investor institusional akan lebih mempengaruhi dalam pengurangan risiko agensi dan asimetri informasi dan akan menghasilkan kredit rating yang lebih baik.

\section{Penelitian Terdahulu}

1. Penelitian (Attig, El Ghoul, \& Guedhami, 2011) yang berjudul

"Institutional Investment Horizon And Firm Credit Ratings". Penelitian ini mengambil sampel pada perusahaan yang listing dibursa Efek Amerika dan membuktikan bahwa terdapat pengaruh antara pandang investasi jangka panjang investor institusi terhadap naiknya kredit rating perusahaan.

2. Penelitian (Attig, Cleary, El Ghoul, \& Guedhami, 2012) yang berjudul "Intitutional Investment Horizon and Investment - Cash Flow Sensitivity". Penelitian ini menggunakan sampel perusahaan yang listing di bursa efek Amerika dan membuktikan bahwa sensitifitas investasi perusahaan dengan menggunakan arus kas internal perusahaan turun sejak adanya investasi yang dilakukan oleh investor institusi yang berinvestasi dalam jangka panjang.

3. Penelitian (Switzer \& Wang, 2017) yang berjudul "Institutional Investment Horizon, the information environment and Firm Credit Risk". Hasil penelitian menunjukkan bahwa investasi jangka panjang yang dilakukan oleh investor institusi akan mengurangi risiko kredit perusahaan.

\section{Hipotesa}

H1: Terdapat pengaruh antara pandangan investasi jangka panjang investor institusional terhadap kredit rating perusahaan.

\section{METODE PENELITIAN}

\section{Populasi dan Sampel}

Objek penelitian ini adalah perusahaan yang terdaftar di Bursa Efek Indonesia dari tahun 2017-2018. Pemilihan sampel dalam penelitian ini menggunakan metode purposive sampling dimana yang menjadi sampel dalam penelitian ini adalah

1. Perusahaan yang menerbitkan laporan keuangan selama tahun pengamatan,

2. Menggunakan mata uang Rupiah,

3. Memiliki kepemilikan institusional lebih dari $5 \%$, dan

4. Memiliki kredit rating yang terdaftar di lembaga pemeringkat kredit di Indonesia. 


\section{Teknik Pengumpulan Data}

Penelitian ini menggunakan data sekunder dari perusahaan yang terdaftar di Bursa Efek Indonesia (BEI) tahun 20172018. Data-data yang digunakan dalam penelitian adalah perusahaan yang memiliki laporan keuangan dan laporan tahunan (annual report) lengkap dari tahun 2017-2018 yang diperoleh dari Bursa Efek Indonesia (BEI) melalui situs www.idx.co.

\section{Definisi Operasional dan Pengukuran Variabel}

Penelitian ini membahas dua variabel, yakni variabel bebas dan variabel terikat. Variabel bebas adalah merupakan variabel yang mempengaruhiatau yang menjadi sebab perubahannya atau timbulnya variabel terikat.

\section{Variabel Dependen}

Variable dependen dalam penelitian ini adalah kredit rating perusahaan yang akan diukur dengan skala ordinal yaitu: Angka 8 untuk peringkat AAA, 7 untuk AA, 6 untuk A, 5 untuk BBB, 4 untuk BB, 3 untuk B, 2 untuk CCC, 1 untuk

\section{Variabel Independen}

Variable independent dalam penelitian ini adalah pandangan investasi investor institusional (PIII) yang diukur dengan persamaan yang dikembangkan oleh Gaspar et al (2005) dengan menghitung nilai churn rate:

$$
\mathrm{CR}_{k, t}=\frac{\sum_{i=1}^{N_{k, t}}\left|S_{k, i, t} P_{i, t}-S_{k, j, t-1} P_{i, t-1}-S_{k, i, t-1} \Delta P_{i, t}\right|}{\sum_{i=1}^{N_{k t}} \frac{S_{k, t, t} P_{i, t}-S_{k, t, 1} P_{t, t-1}}{2}}
$$

Keterangan:

$\mathrm{N}_{\mathrm{k}, \mathrm{t}}=$ jumlah dari perusahaan yang didalam nya ada investor institusional

$\mathrm{S}_{\mathrm{k}, \mathrm{i}, \mathrm{t}}=$ jumlah perusahaan yang sahamnya dimiliki oleh investor institusional pada kuartal t.

$\mathrm{P}_{\mathrm{i}, \mathrm{t}} \quad=$ Harga saham pada kuartal $\mathrm{t}$ Churn rate mengukur frekuensi yang mana investor institusi mengubah posisinya dalam kepemilikan saham perusahaan. Tingginya nilai CR mengindikasikan bahwa investor institusional memiliki pandangan investasi jangka pendek.

Selanjutnya akan dihitung nilai rata-rata CR selama 4 kuartal kebelakang:

$$
\begin{gathered}
\mathrm{AVG}_{-} \mathrm{CR}_{k, t}=\frac{1}{4} \sum_{r=1}^{4} \mathrm{CR}_{k, t-r+1} \\
\mathrm{WACR}_{j, t}=\sum_{k=1}^{M_{j i}} w_{k, i, t} \mathrm{AVG}_{-} \mathrm{CR}_{k, t}
\end{gathered}
$$

Dimana w adalah persentase kepemilikan instusional di perusahaan, kepemilikan investor institusional dibagi menjadi kepemilikan jangka panjang dan jangka pendek, dikatakan jangka panjang apabila memiliki nilai AVG CR batas bawah dan jangka pendek yang memiliki nilai AVG CR batas atas.

\section{Variabel kontrol}

Ukuran Perusahaan (Size) menggambarkan besar kecilnya suatu perusahaan, dalam 
penelitian ini ukuran perusahaan diukur dengan nature log dari total asset perusahaan.

Rasio interest coverage yaitu rasio hutang dan profitabilitas yang digunakan untuk menentukan seberapa mudah suatu perusahaan dapat membayar bunga pinjamannya. Yaitu EBIT + beban bunga / beban bunga.

Rasio Perputaran asset tetap yaitu total asset tetap dibagi dengan total asset.

Kerugian (loss) merupakan indicator 1 jika laba bersih sebelum extraordinary items adalah negatif pada tahun ini dan tahun sebelumya, dan 0 jika kebalikannya.

\section{Teknik Analisis Data}

Menurut Sugiyono (2008) analisis data dalam penelitian ini dilakukan dengan beberapa tahap. Tahap pertama akan dilakukan analisis deskriptif berdasarkan data empiris yang diperoleh untuk semua variabel. Pada tahap kedua akan dilakukan analisis dengan menggunakan regresi linier berganda. Adapun persamaan dari regresi linier berganda ini adalah:

Rating $=\alpha+\beta 1$ PIII $+\beta 2$ SIZE $+\beta 3$ IC $+\beta 4$ PAT $+\beta 5$ Loss $+e$

Sebelum dilakukan regresi akan dilakukan uji asumsi klasik atas data yaitu uji normalitas dengan uji kolmogorov smirnov dan uji autokorelasi dengan melihat nilai durbin watson, uji heteroskedastisitas dengan uji gletser dan multikolinieritas dengan melihat nilai VIF, dimana dikatakan bebas multikolinieritas apabila dibawah 10. Setelah itu akan diuji kelayakan model (uji F) dimana model dikatakan layak apabila tingkat signifikansinya kurang dari 0,05. Setelah itu dilihat berapa nilai $\mathrm{R}^{2}$ nya untuk mengetahui berpaa persen variabel independen mempengaruhi variabel dependennya. Uji terakhir dari analisis regresi adalah untuk melihat berapa besar variabel independen memiliki hubungan dan pengaruh terhadap variabel dependen. Dimana tingkat signifikasinya dikatakan berpengaruh apabila dibawah 0,05 .

\section{HASIL PENELITIAN DAN}

\section{PEMBAHASAN}

\section{Deskripsi Data}

Penelitian ini menggunakan data sekunder dari perusahaan yang terdaftar di Bursa Efek Indonesia (BEI).

Tabel 1: Sampel Penelitian

\begin{tabular}{lc}
\hline \multicolumn{1}{c}{ Perusahaan Sampel Penelitian } & $\begin{array}{c}\text { Jumlah } \\
\text { Sampel }\end{array}$ \\
\hline $\begin{array}{l}\text { Perusahaan yang terdaftar di Bursa } \\
\text { Efek Indonesia tahun 2017-2018 }\end{array}$ & 456 \\
$\begin{array}{l}\text { Laporan keuangan yang tidak } \\
\text { lengkap tahun 2017-2018 }\end{array}$ & $(56)$ \\
$\begin{array}{l}\text { Perusahaan yang menggunakan } \\
\text { mata uang selain rupiah }\end{array}$ & $(15)$ \\
$\begin{array}{l}\text { Perusahaan yang memiliki } \\
\text { kepemilikan institusional }\end{array}$ & $(140)$ \\
$\begin{array}{l}\text { Perusahaan yang tidak terdaftar } \\
\text { Jumlah Sampel Perusahaan }\end{array}$ & $(153)$ \\
$\begin{array}{l}\text { Jumlah sampel perusahaan 2017- } \\
\text { 2018 ( 85 x2 tahun) }\end{array}$ & 85 \\
\hline
\end{tabular}

Berdasarkan hasil penelitian didapatkan sampel selama 2 tahun periode penelitian 
2017-2018 dengan teknik pengambilan sampel dalam penelitian ini menggunakan metode purposive sampling. Sampel perusahaan yang digunakan dalam penelitian ini disajikan pada Tabel 1.

\section{Statistik Deskriptif}

Statistik deskriptif memberikan gambaran awal variabel penelitian dan digunakan untuk mengetahui karakteristik sampel yang digunakan dalam penelitian. Pada penelitian ini, statistik deskriptif yang digunakan meliputi maksimum, minimum, rata-rata dan standar deviasi (Ghozali, 2011). Statistik deskriptif dalam penelitian ini digunakan untuk menggambarkan seluruh variabel yang digunakan dalam penelitian ini, yaitu kredit rating, (KR) pandangan investasi institusional (PIII), ukuran perusahaan (UP), rasio interest coverage (IC), rasio perputaran asset tetap (PAT), dan kerugian (loss). Deskriptif statistik pada penelitian ini disajikan pada Tabel 2.

Tabel 2: Statistik Deskriptif Variabel Penelitian

\begin{tabular}{cccccc}
\hline Var & N & Min & Max & Mean & $\begin{array}{c}\text { Std. } \\
\text { Dev }\end{array}$ \\
\hline KR & 170 & 0,000 & 8,000 & 5,000 & 2,0367 \\
PIII & 170 & 0,730 & 2,9700 & 1,1236 & 0,2576 \\
UP & 170 & 1,006 & 31,382 & 28,831 & 4,3476 \\
IC & 170 & $-39,320$ & 31,782 & 97,5364 & 998232 \\
PAT & 170 & 0,0011 & 3,2839 & 0,384 & 0,4241 \\
& & & & & 2 \\
LOSS & 170 & 0 & 1,000 & 0,881 & 0,3841 \\
2
\end{tabular}

\section{Pengujian Asumsi Klasik}

Pengujian asumsi klasik dalam penelitian ini meliputi uji normalitas, uji autokorelasi, uji multikolinieritas, dan uji heterokedastisitas. Uji asumsi klasik dalam penelitian ini dilakukan dengan alat uji Statistical Package for the Social Sciences (SPPS) versi 20.

\section{Uji Normalitas}

Uji normalitas bertujuan untuk menguji apakah dalam model regresi, kedua variabel yakni variabel independen dan variabel dependen memiliki distribusi normal atau tidak (Ghozali, 2011). Hasil pengujian normalitas untuk seluruh variabel disajikan pada Tabel 3.

Tabel 3: Hasil Uji Normalitas

\begin{tabular}{ll}
\hline \multicolumn{2}{c}{ Persamaan 1 } \\
\hline Kolmogorov-Smirnov Z & 0,547 \\
Asymp. Sig. (2-tailed) & 0,926 \\
Keterangan & Data Normal \\
\hline
\end{tabular}

\section{Uji Autokorelasi}

Uji autokorelasi dilakukan untuk mengetahui apakah terjadi korelasi antara kesalahan pengganggu pada periode $t$ dengan kesalahan pada periode $t-1$. Pengujian autokorelasi dilakukan dengan melihat nilai $d$ atau koefisien Durbin Watson $(D-W)$. Hasil pengujian autokorelasi disajikan pada tabel sebagai berikut:

Tabel 4: Hasil Uji Autokorelasi

\begin{tabular}{cccccc}
\hline \multicolumn{5}{c}{ Persamaan 1 } \\
\hline K & DL & DU & DW & KRITERIA & Keterangan \\
\hline 2 & 1,44 & 1,68 & 1,89 & $1,68<$ DW $<2,32$ & $\begin{array}{c}\text { Bebas Auto- } \\
\text { korelasi }\end{array}$ \\
\hline
\end{tabular}




\section{Uji Multikolinieritas}

Uji multikolinieritas dilakukan dengan tujuan untuk menguji apakah pada model regresi ditemukan adanya korelasi di antara variabel independen. Untuk melihat ada atau tidaknya masalah multikolinieritas dapat dilihat dari nilai Tolerance dan Variance Inflation Factor (VIF). Hasil uji multikolinieritas dapat dilihat pada Tabel 5 sebagai berikut:

Tabel 5: Hasil Uji Multikolinieritas

\begin{tabular}{|c|c|c|c|}
\hline \multicolumn{4}{|c|}{ Persamaan 1} \\
\hline Var. & Tol & VIF & Keterangan \\
\hline \multirow{2}{*}{ PII } & \multirow{2}{*}{0,333} & \multirow{2}{*}{3,005} & Bebas \\
\hline & & & Multikolinearitas \\
\hline \multirow{2}{*}{ UP } & \multirow{2}{*}{0,337} & \multirow{2}{*}{2,970} & Bebas \\
\hline & & & Multikolinearitas \\
\hline \multirow{2}{*}{ IC } & \multirow{2}{*}{0,0974} & \multirow{2}{*}{1,028} & Bebas \\
\hline & & & Multikolinearitas \\
\hline \multirow{2}{*}{ PAT } & \multirow{2}{*}{0,858} & \multirow{2}{*}{1,166} & Bebas \\
\hline & & & Multikolinearitas \\
\hline \multirow{2}{*}{ LOSS } & \multirow{2}{*}{0,964} & \multirow{2}{*}{1,037} & Bebas \\
\hline & & & Multikolinearitas \\
\hline
\end{tabular}

\section{Uji Heteroskedastisitas}

Pengujian heteroskedastisitas bertujuan untuk menguji apakah dalam model regresi terjadi ketidaksamaan variance dari residual satu observasi ke observasi yang lain. Jika koefisien korelasi semua variabel terhadap residual > 0,05 dapat disimpulkan bahwa model regresi tidak terjadi heteroskedastisitas. Hasil uji heteroskedastisitas dapat dilihat pada Tabel 6.
Tabel 6: Hasil Uji Heteroskedastisitas

\begin{tabular}{cccl}
\hline & \multicolumn{2}{c}{ Persamaan 1 } \\
\hline Var & Tol & Sig & Keterangan \\
\hline PII & 0,297 & 0,767 & $\begin{array}{l}\text { Bebas } \\
\text { Heteroskedastisitas }\end{array}$ \\
\hline UP & 1,264 & 0,211 & $\begin{array}{l}\text { Bebas } \\
\text { Heteroskedastisitas }\end{array}$ \\
\hline IC & $-0,088$ & 0,930 & $\begin{array}{l}\text { Bebas } \\
\text { Heteroskedastisitas }\end{array}$ \\
\hline PAT & 1,520 & 0,133 & $\begin{array}{l}\text { Bebas } \\
\text { Heteroskedastisitas }\end{array}$ \\
LOSS & 1,910 & 0,061 & $\begin{array}{l}\text { Bebas } \\
\text { Heteroskedastisitas }\end{array}$ \\
\hline
\end{tabular}

\section{Pengujian Hipotesis}

Pengujian hipotesis dalam penelitian ini bertujuan untuk melihat apakah Pandangan investasi jangka panjang investor institusioanal terhadap kredit rating perusahaan. Untuk membuktikan hal tersebut, dilakukan pengujian hipotesis pertama disajikan pada tabel 7 .

Tabel 7: Pengujian Hipotesis Pertama

\begin{tabular}{lccc}
\hline & \multicolumn{3}{c}{ Persamaan 1 } \\
\cline { 2 - 4 } & Koef & T & Sig \\
\hline PII & 0,029 & 1,726 & 0,000 \\
UP & $-0,005$ & 0,594 & 0,000 \\
IC & 0,234 & 2,547 & 0,000 \\
PAT & 0,156 & 1,842 & 0,000 \\
LOSS & 1,000 & 0,00 & 0,000 \\
Adjusted $\mathrm{R}^{2}$ & \multicolumn{3}{c}{1,000} \\
F & \multicolumn{3}{c}{181765,107} \\
\hline
\end{tabular}

Berdasarkan Tabel 7, pengujian hipotesis untuk model pertama didapatkan nilai statistik $F$ sebesar 181765,107 dan tingkat signifikansi $0,00<0,05$ maka dapat disimpulkan model tersebut fit dan variabel pandangan investasi investor dan kredit rating perusahaan secara serentak dan signifikan mempengaruhi variabel nilai 
Nominal: Barometer Riset Akuntansi dan Manajemen

P-ISSN: 2303-2065 E-ISSN: 2502-5430

Volume 10 No 2 (2021)

perusahaan yang diukur dengan menurunkan risiko perusahaan yang hasilnya menggunakan rasio Tobinsq. Nilai adjusted $\mathrm{R}^{2}$ sebesar 1,00 menunjukkan bahwa seluruh variabel independen menjelaskan variabel dependennya.

\section{Pembahasan}

Variabel pandangan investor terhadap kredit rating perusahaan dengan tingkat signifikansi 0,00 lebih kecil dari 0,05. Artinya, pandangan investor terhadap kredit rating perusahaan secara signifikan terbukti berpengaruh. Berdasarkan teori sinyal dimana sinyal berupa informasi mengenai apa yang telah dilakukan oleh manajemen untuk merealisasikan keinginan dari pemilik. Sinyal dapat berupa promosi atau informasi lain yang menyatakan bahwa perusahaan lebih baik dari perusahaan lainnya.

Pada pandangan investasi investor institusional juga memiliki peran tata kelola untuk menjaga dan mengawasi efek dari asimetri informasi. Investor institusi yang cenderung memiliki pandangan investasi jangka panjang lebih memainkan peran pengawasan dibandingkan dengan investor institusional yang memiliki pandangan investasi jangka pendek. Semakin baiknya tata kelola di dalam perusahaan akan berdampak pada kualitas perusahaan dan dapat direfleksikan dalam peringkat kredit perusahaan. (Ashbaugh-Skaife et al., 2006; Bhojraj \& Sengupta, 2003) mengatakan bahwa tata kelola perusahaan akan mampu 
setengah data lainnya tidak memenuhi

kriteria sampel.

\section{DAFTAR PUSTAKA}

Ashbaugh-Skaife, H., Collins, D. W., \& LaFond, R. (2006). The effects of corporate governance on firms' credit ratings. Journal of Accounting and Economics, 42(1-2), 203-243. https://doi.org/10.1016/j.jacceco.2006. 02.003

Attig, N., Cleary, S., El Ghoul, S., \& Guedhami, O. (2012). Institutional investment horizon and investment-cash flow sensitivity. Journal of Banking and Finance, 36(4), 1164-1180. https://doi.org/10.1016/j.jbankfin.2011. 11.015

Attig, N., El Ghoul, S., \& Guedhami, O. (2011). Institutional investment horizon and firm credit ratings. In International Finance Review (Vol. 12). https://doi.org/10.1108/S15693767(2011)0000012005

Bhojraj, S., \& Sengupta, P. (2003). Effect of Corporate Governance on Bond Ratings and Yields: The Role of Institutional Investors and Outside Directors. Journal of Business, 76(3), 455-475. https://doi.org/10.1086/344114

Blume, M. E., Lim, F., \& Mackinlay, A. C. (1998). The declining credit quality of U.S. corporate debt: Myth or reality? Journal of Finance, 53(4), 1389-1413. https://doi.org/10.1111/00221082.00057

Brigham, E. F., \& Houston, J. F. (2001). Manajemen Keuangan (8th ed.). Jakarta: Erlangga.

Connelly, B., Tihanyi, L., Certo, S., \& Hitt, M. (2010). Marching to the beat of different drummers: The influence of institutional owners on competitive actions. Academy of Management Journal, 53(4), 723-742. https://doi.org/10.5465/amj.2010.52814 589

Ghozali, I. (2011). Aplikasi Analisis Multivariate Dengan Program SPSS. Semarang: Badan Penerbit Universitas Diponegoro.

Pujiati. (2015). Pengaruh Kepemikian Manajerial, Kepemilikan Institusional, dan Kesempatan Investasi Terhadap Kebijakan Dividen Dengan Likuiditas Sebagai Variabel Moderasi (Studi Empiris pada Perusahaan Sektor Industri Barang Konsumsi Yang Terdaftar di BEI Periode 2008-20. Universitas Negeri Yogyakarta.

Rahardjo, S. (2004). Panduan Investasi Obligasi (1st ed.). Jakarta: Gramedia Pustaka Utama.

Sengupta, P. (1998). Corporate the Disclosure Cost of Partha Sengupta Quality Debt and. The Accounting Review, 73(4), 459-474.

Shleifer, A., \& Vishny, R. W. (1997). A Survey of Corporate Goveranance. The Journal Of Finance, Vol. 52, pp. 737783.

Sugiyono. (2008). Metode Penelitian Bisnis. Bandung: Alfabeta.

Switzer, L. N., \& Wang, J. (2017). Institutional investment horizon, the information environment, and firm credit risk. Journal of Financial Stability, 29, 57-71. https://doi.org/10.1016/j.jfs.2017.02.00 2 